University of Rhode Island

DigitalCommons@URI

The Rhode Island Current Conditions Index

Economics

$2-2010$

\title{
Rhode Island Current Conditions Index - February 2010
}

Leonard Lardaro

University of Rhode Island, lardaro@uri.edu

Follow this and additional works at: https://digitalcommons.uri.edu/ricci

Part of the Econometrics Commons

Terms of Use

All rights reserved under copyright.

\section{Recommended Citation}

Lardaro, Leonard, "Rhode Island Current Conditions Index - February 2010" (2010). The Rhode Island Current Conditions Index. Paper 2.

https://digitalcommons.uri.edu/ricci/2

This Article is brought to you for free and open access by the Economics at DigitalCommons@URI. It has been accepted for inclusion in The Rhode Island Current Conditions Index by an authorized administrator of DigitalCommons@URI.For more information, please contact digitalcommons-group@uri.edu. 


\section{GURRENT}
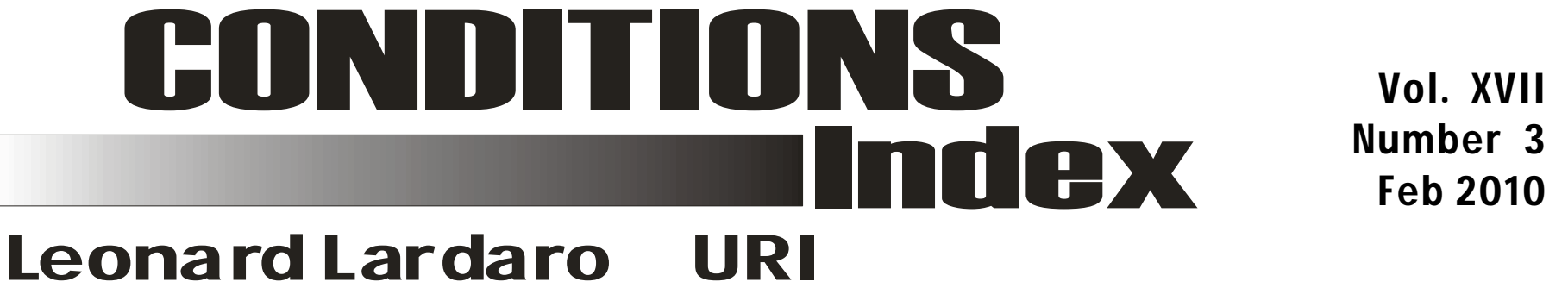

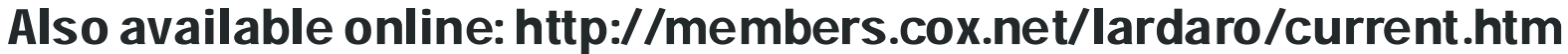

Prior to the April flooding, Rhode Island's economy was continuing to move ever closer to a cyclical bottom, allowing us to begin visualizing an end of the current recession which has now lasted over two and a half years. February's Current Conditions Index was further proof of this. The February $\mathrm{CCl}$ once again reached its neutral value of 50 , only the second time this has occurred since mid-2007. Although the flooding that has so devastated Rhode Island was not a cyclical event, it will nonetheless generate substantial negative effects on Rhode Island's economy throughout most of the remainder of 2010. So, starting in April, recent improvements in $\mathrm{CCl}$ values will be lost for a while, as the impact of the flooding overwhelms whatever cyclical momentum exists.

Although it now seems irrelevant (something akin to July and August data releases after 9/11), Rhode Island's economy did manage to turn in a strong performance in February. The $\mathrm{CCl}$ 's

\begin{tabular}{|l|r|}
\hline \multicolumn{2}{|c|}{ CCI Indicators - \% Change } \\
\hline Government Employment & -1.9 \\
\hline US Consumer Sentiment & $31.1 \mathbf{Y}$ \\
\hline Single-Unit Permits & $191.8 \mathbf{Y}$ \\
\hline Retail Sales & $5.0 \mathbf{Y}$ \\
\hline Employment Services J obs & -10.2 \\
\hline Priv. Serv-Prod Employment & -1.9 \\
\hline Total Manufacturing Hours & -6.6 \\
\hline Manufacturing Wage & $2.3 \mathbf{Y}$ \\
\hline Labor Force & $2.7 \mathbf{Y}$ \\
\hline Benefit Exhaustions & 8.4 \\
New Claims & $-38.2 \mathbf{Y}$ \\
\hline Unemployment Rate & 28.3 \\
\hline \multicolumn{2}{|c|}{ Y I Improved Value } \\
\hline
\end{tabular}

value of 50 indicates that six of twelve indicators improved compared to a year earlier. On a monthly basis, six indicators improved, while five of the other six were close to improving. Admittedly, some of this results from relatively easy comps in February of 2009. But Rhode Island's economic momentum in February was improving. Prior to the flooding, it was not inconceivable for Rhode Island's economy to have reached a bottom around July of this year. The only question now is whether a bottom will ever be reached at any time this year.

Looking at the February indicator performance, US Consumer Sentiment continued to be our "star" performer, rising by 31.1 percent in February, its eleventh consecutive year-overyear improvement. Our state's Labor Force rose again, increasing by a surprising 2.7 percent. Growth in the Manufacturing Wage remained rapid in February, at a 2.3 percent rate, sustaining a string of growth rates above 2 percent since last September. Once again, Single-Unit
Permits surged by over 100 percent compared to a year ago $(+191.8 \%)$. Why? Since there were only 16 permits for the entire state last February. So, prior to the flooding, there continued to be virtually no new home construction in Rhode Island. Post-flood rebuilding and repairs will actually help Rhode Island's housing sector in coming months. Another improving indicator, Retail Sales, will not fare as well. For February, Retail Sales grew by a very healthy 5 percent compared to a year ago, rising on a monthly basis for the last three months. The total shutdown of Warwick Mall after the flooding will by itself dramatically lower Retail Sales starting for at least April and May. The last improving indicator, New Claims, a leading indicator that measures layoffs, fell by 38.2 percent, its seventh improvement in the last eight months.

February's performance was not without its negatives. Future job prospects based on Employment Service Jobs, a leading indicator, remained discouraging, as these fell 10.2 percent compared to a year ago. In spite of this, this indicator has stabilized on a monthly basis since last March. Total Manufacturing Hours fell again, but by a less than doubledigit rate (6.6 percent) compared to last year. Private Service-Producing Employment declined again, by 1.9 percent, ironically its "best" performance in quite some time, even though our Unemployment Rate remained stuck at 12.7 percent. Government Employment, driven largely by budget woes, declined by another 1.9 percent, and Benefit Exhaustions, which reflects long-term unemployment, rose by "only" 8.4 percent.

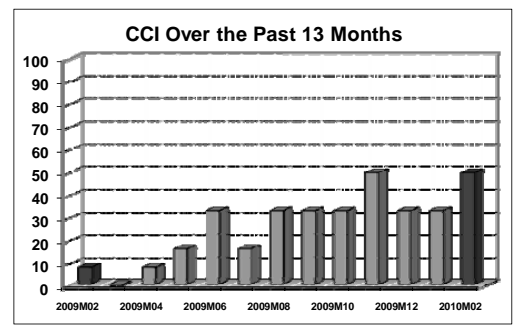

\section{THE BOTTOM LINE}

Prior to the recent flooding, Rhode Island's economy was gaining momentum, as the $\mathrm{CCl}$ has shown. Expect a mixed outcome as the result of the floods. In the near term, economic momentum will clearly slow, as negatives offset any cyclical gains that occur. Once rebuilding starts and federal money begins to flow into Rhode Island, an eventual recovery will begin and initially, at least, growth will exceed what it otherwise would have been.

\begin{tabular}{|c|c|c|c|c|c|c|c|c|c|c|c|c|}
\hline & Jan & Feb & Mar & Apr & May & J un & $\mathbf{J} \mathbf{u l}$ & Aug & Sep & Oct & Nov & Dec \\
\hline 2009 & 17 & 8 & 0 & 8 & 17 & $33 \downarrow$ & $17 \downarrow$ & 42 & 33 & 42 & 50 & 33 \\
\hline 2010 & 33 & 50 & & & & & & & & & & \\
\hline
\end{tabular}

